\title{
Review \\ The Relationship between Modern Fad Diets and Kidney Stone Disease: A Systematic Review of Literature
}

\author{
Yazeed Barghouthy ${ }^{1}$ (D), Mariela Corrales ${ }^{1}$ and Bhaskar Somani ${ }^{2, *(D)}$ \\ 1 GRC n²0, Groupe de Recherche Clinique sur la Lithiase Urinaire, Hôpital Tenon, Sorbonne Université, \\ F-75020 Paris, France; yazeedmail@gmail.com (Y.B.); mariela_corrales_a@hotmail.com (M.C.) \\ 2 Department of Urology, University Hospital Southampton NHS Trust Southampton, \\ Southampton SO16 6YD, UK \\ * Correspondence: bhaskarsomani@yahoo.com
}

check for updates

Citation: Barghouthy, Y.; Corrales, M.; Somani, B. The Relationship between Modern Fad Diets and Kidney Stone Disease: A Systematic Review of Literature. Nutrients 2021, 13, 4270. https://doi.org/10.3390/ nu13124270

Academic Editor: Adamasco Cupisti

Received: 25 October 2021

Accepted: 26 November 2021

Published: 26 November 2021

Publisher's Note: MDPI stays neutral with regard to jurisdictional claims in published maps and institutional affiliations.

Copyright: (c) 2021 by the authors. Licensee MDPI, Basel, Switzerland. This article is an open access article distributed under the terms and conditions of the Creative Commons Attribution (CC BY) license (https:// creativecommons.org/licenses/by/ $4.0 /)$.
Abstract: Objectives: Kidney stone disease (KSD) has a strong association with diet metabolic syndrome. This review aims at exploring the lithogenic risk posed by the current most popular diets. Our approach was to search for the effect of each diet type on the major urinary risk factors, to try to draw conclusions regarding the association of a specific diet type and KSD. Methods: This systematic review searched for the available literature exploring the association between the existing popular fad diets and KSD. Articles in English, French and Spanish were included, without restriction of the search period with the final search done in August 2021. Results: Total number of studies and studies for each diet type was as follows: 22 articles for the low carbohydrate diet, 20 articles for high protein diets, 26 articles for vegetarian and vegan diets. There exists a substantial variability in different low carbohydrate and high protein diets, and considerable overlap between modern popular fad diets. High carbohydrate intake might increase urine uric acid, calcium and oxalate levels. High protein diets increase urine calcium and uric acid and lower urine $\mathrm{pH}$ and citrate. Consumption of fruits and vegetables increases the urinary volume and urinary citrate. In vegan diets, sufficient daily calcium intake is important to avoid possible secondary hyperoxaluria. Conclusions: Few studies evaluated the direct relationship between modern fad diets and KSD. In general, the reduction of carbohydrate in the diet, and counterbalancing protein rich diets with sufficient intake of fruits and vegetables, seem to play a protective role against KSD formation. Maintaining sufficient calcium intake in vegan and vegetarian diets is important. Additional research is needed to directly evaluate the link between KSD and each diet type.

Keywords: diet; fad diets; low carbohydrate; high protein; low fat; Atkins; zone; ketogenic; Dukan; Mediterranean; vegetarian; vegan; paleo; nephrolithiasis; urinary stones; kidney stones; urolithiasis; risk; kidney calculi

\section{Introduction}

Kidney stone disease (KSD), with an estimated prevalence of up to $10-14 \%$ in industrialized nations [1,2], is closely related to obesity and other components of the Metabolic Syndrome (Mets) [3]. The increase in prevalence of this ensemble of diseases in recent decades is attributed mainly to the changes in lifestyle habits and dietary intake, notably the significant increase in carbohydrate and protein intake [4-8].

Kidney stones disease is a multifactorial process, influenced by dietary, urinary, and genetic factors. The early steps involve mineral precipitation secondary to reduced fluid intake and over-saturation of their urinary levels, followed by crystal nucleation, aggregation, and growth to particles measuring a few hundred microns. In turn, these particles might agglomerate into small stones that continue to grow in the renal collecting system, in different rates, according to the underlying pathology. While all stones share the common pathologic pathway of a disequilibrium between promoting and inhibitory factors for stone formation, each family of stones has a more characteristic set of risk factors. Calcium 
stones, whether associated to oxalate or phosphate, represent the majority of stones. They are influenced by excessive urine calcium and oxalate levels, due to high dietary intake or intestinal malabsorption syndromes, or a rise of urine calcium due to parathyroid disease. Uric acid stones on the other hand, which constitute almost $10-15 \%$ of stones, are closely linked to high dietary protein and uric acid intake, and to metabolic acidosis in addition to insulin-dependence.

Our diet is composed mainly of three major nutrients-carbohydrates $(4 \mathrm{kcal} / \mathrm{gm})$, protein $(4 \mathrm{kcal} / \mathrm{gm})$, and fat $(9 \mathrm{kcal} / \mathrm{gm})$, with the recommended composition range being $45-55 \%, 10-35 \%$, and 20-30\% respectively, accounting for around $35 \mathrm{Kcal} / \mathrm{Kg}$ per day [9]. While multiple definitions exist for the term "Fad diets", the common ground for all these definitions is that fad diets are popular "weight loss" regimens, promoted throughout popular media outlets and sometimes endorsed by celebrities. They usually focus on manipulation and elimination of certain nutritional components rather than larger lifestyle and health modification based on scientific research. Furthermore, fad diets in many cases are economic tools used to promote sales of books or products such as "weight-loss" programs. Three main categories of diets are available, those based on the manipulation of macronutrient content such as low carbohydrate diets or protein rich diets; those based on the restriction of specific foods and/or food groups such as the vegan or vegetarian diets; and, finally, diets based on intermittent fasting such as the "moon diet". In the last twenty years, a number of fad diets have experienced growing popularity, sometimes under the influence of social media and popular trends. The common goal of these diet strategies, in addition to losing surplus weight, is to reduce the risks for cardiac disease and diabetes mellitus [10]. While some studies showed an advantage for weight loss in the short term for mainly for protein rich low carb diets, the results for the best strategy for weight loss in the long term are a matter of debate. Moreover, fad diets demonstrate the social pressure for achieving an idealized body image through control of nutrition [11].

The co-existence of KSD and obesity, and the prescription or self-adherence of certain diets to combat obesity, leads us to inquire about what effect these different diets would have on urinary risk factors for stone formation. However, the real impact of these fad diets, on the risk of kidney stones' formation, has not been thoroughly evaluated. Furthermore, despite not being the focus of this paper, it should be noted that diets involving changes in macronutrient composition or acquiring a state of negative energy balance might cause hormonal and metabolic changes in the body, affecting multiple organ systems. For example, diets refraining from dairy products intake might expose patients to reduced mineral density pathologies, and diets involving intermittent fasting can lead the body to a ketogenic metabolic mode, which are not suitable for all patients [10]. In addition, adhering to a diet without proper information, guidance and support can lead to different psychological perturbations including body-weight image disturbances.

This review aims at exploring the lithogenic risk posed by the current most popular diets. Nevertheless, numerous types of diets have evolved and others have been modifications of already existing ones. In addition, there exists a considerable overlap between different families of diets, as in the case of carbohydrate low and protein rich diets. These factors make it difficult to evaluate the direct specific relationship of each diet with KSD.

In consequence, our approach was to search for the effect of each diet type on the major urinary risk factors, in order to try to draw conclusions regarding the association of a specific diet type and KSD.

\section{Methods}

This systematic review searched for the available literature exploring the association between the existing popular fad diets and KSD. Articles in English, French, and Spanish were included, without restriction of the search period with the final search done in August 2021. Systematic reviews, case reports, editorials letters, comments, and abstracts- were excluded. 


\section{Search Strategy and Study Selection}

A systematic review was performed, using the PubMed-MEDLINE, EMBASE and Scopus databases. The Preferred Reporting Items for Systematic Reviews and Meta-Analyses (PRISMA) statement (Figure 1) was followed in this review. The keywords used were the followings: "Diet", "fad diets", “Low carbohydrate", "ketogenic", "Low Fat", "Atkins", "Zone", “Ketogenic", “Dukan", “Mediterranean", “Vegetarian", “Vegan", "Paleo", “Moon", and "South beach". Search terms included a combination of keywords above with each of the following: "Nephrolithiasis", "Urinary stones", "Kidney stones", “Urolithiasis", "Risk". Two reviewers (Y.B., M.C.) identified all the studies independently and any discrepancy were resolved with mutual consensus. A narrative synthesis rather than a quantified meta-analysis of data was performed, due to the heterogeneity of outcomes.

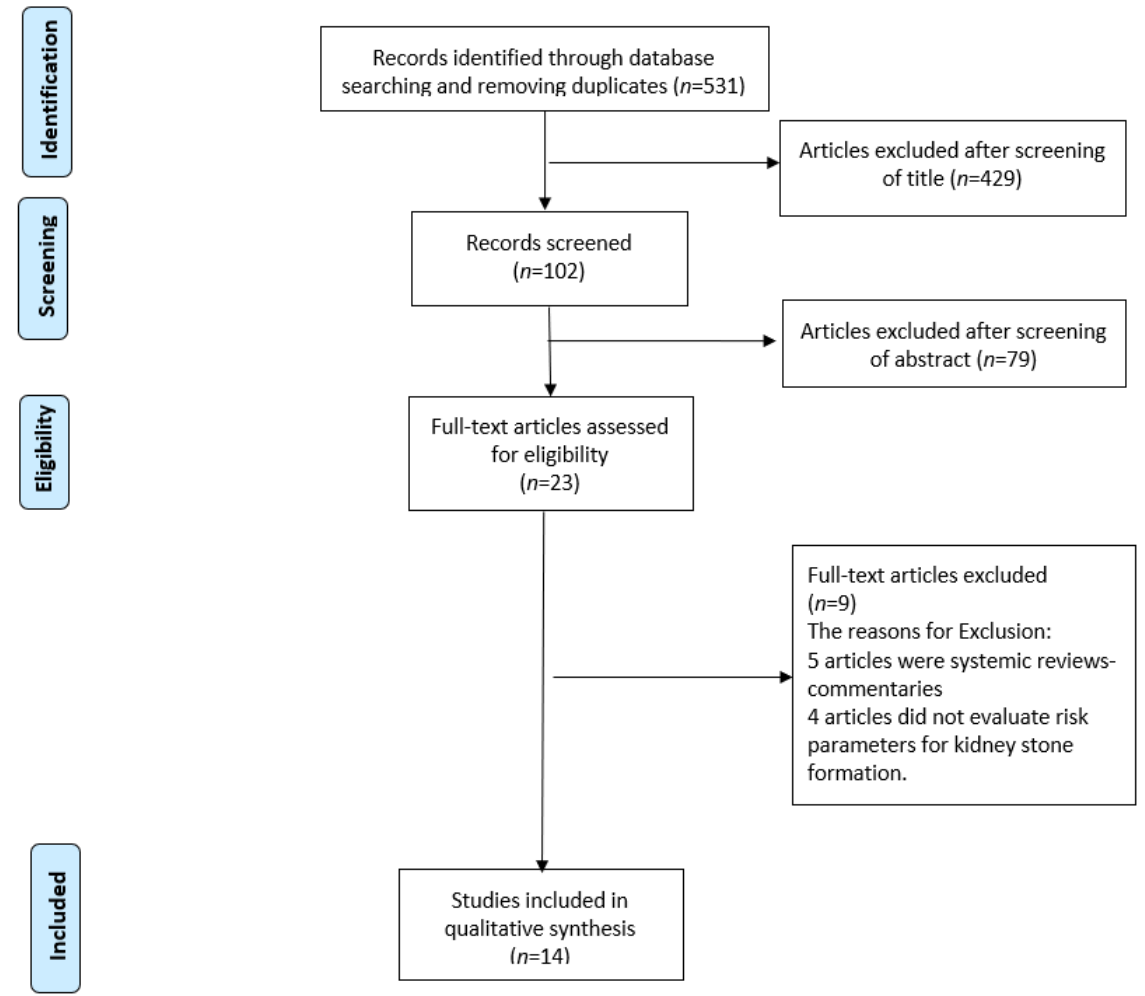

Figure 1. PRISMA flowchart of the included studies.

\section{Diet Types and KSD}

\subsection{Low Carbohydrate (LC) Diet}

Low carbohydrate (low carb, LC) diets are one of the oldest known methods for weight reduction. Multiple modifications of the LC diet exist, with all entailing a reduction of carbohydrates intake in the diet to less than $45-50 \%$ of the total macronutrient intake $[6,12]$.

The common theme to all LC diets is that a lower carbohydrate intake will eventually reduce the levels of circulating insulin levels, switching the body's metabolism away from the anabolic state, in what constitutes the carbohydrate-insulin model, and eventually inducing a relatively rapid weight loss within the first year $[13,14]$.

To compensate for the reduction of carbohydrate intake in the diet, there is an increase in the percentage of protein or fat intake per day $[15,16]$. The various versions of LC diets differ in the percentages of carbohydrate intake reduction, and protein or fat increase, and it is from this increase of the other macronutrients that the overlap with other types of diets exists.

The Atkins diet, probably one of the most popular diets in recent decades, is very low in carbohydrates, with an induction phase of 2-3 months with less than $20 \mathrm{~g}$ per day of carbohydrate intake and subsequent balancing and maintenance phases with less than $50 \mathrm{~g}$ per day of carbohydrate intake. The Zone diet includes a mild reduction in 
carbohydrate intake to $40 \%$ of total macronutrient intake, and a mild increase of protein and fat intake to $30 \%$ each of the total nutritional intake per day. The South Beach diet, a more recent approach, is a fiber-rich diet that promotes intake of complex carbs, or so-called good carbs, from various sources such as fruits, vegetables, whole grains, and beans, while avoiding simple or "bad" carbs, represented by sugar and industrial syrups and sweeteners [10,16-18]. An extreme modification of a LC diet, the ketogenic or "keto" diet, induces a nutritional ketosis and thus production of ketone bodies from fat tissue in the body, by increasing energy intake from fat, and significant restriction of carbohydrate intake to $20-50 \mathrm{~g}$ per day and subsequent glycogen storages' depletion. This diet is mainly used in the management of refractory cases of epilepsy [19].

\subsection{LC Diets and Urinary Risk Factors for KSD}

\subsubsection{Calcium}

Previous research, backed by large epidemiological studies, have demonstrated that an oral load of simple carbohydrates, such as glucose or xylitol, can induce hypercalciuria and increase the risk for KSD [20-22] (Table 1). It is worth mentioning that the demonstrated hypercalciuria is not attributed to the secretion of insulin in response to sugar intake [23].

Table 1. Summary of diets and potential effect on urinary parameters (Carb: Carbohydrates, CaOx: Calcium Oxalate).

\begin{tabular}{|c|c|c|c|c|c|}
\hline Diet & Urinary Calcium & Urinary Oxalate & Urinary Uric Acid & Urinary Citrate & General Risk for Kidney Stones \\
\hline 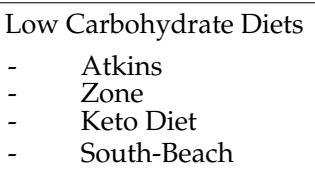 & Mild decrease & Mild decrease & Decrease & - & $\begin{array}{l}\text { Possible decreased risk. However, } \\
\text { potential benefits of lower carb } \\
\text { intake might be offset by } \\
\text { increased protein intake. }\end{array}$ \\
\hline $\begin{array}{l}\text { Protein Rich Diets } \\
-\quad \text { Doucan } \\
-\quad \text { Paleo }\end{array}$ & Increase & $\begin{array}{l}\text { Possible increase } \\
\text { in CaOx Stone } \\
\text { formers }\end{array}$ & Increase & Decrease & $\begin{array}{l}\text { Possible Increased risk if protein } \\
\text { intake exclusively from } \\
\text { animals-can be counterbalanced } \\
\text { by protein intake from vegetables. }\end{array}$ \\
\hline $\begin{array}{l}\text { Vegetarian Diets } \\
-\quad \text { DASH diets }\end{array}$ & $\begin{array}{l}\text { No change if } \\
\text { dairy product } \\
\text { intake } \\
\text { maintained }\end{array}$ & $\begin{array}{l}\text { Possible increase } \\
\text { with intake of } \\
\text { high oxalate } \\
\text { vegetables }\end{array}$ & - & Increase & $\begin{array}{l}\text { Probable decreased risk under the } \\
\text { condition of normal calcium } \\
\text { intake and avoidance of high } \\
\text { oxalate-content vegetables (e.g., } \\
\text { Spinach, Rhubarb). }\end{array}$ \\
\hline Vegan Diets & $\begin{array}{l}\text { Decrease if } \\
\text { dietary intake } \\
\text { not maintained }\end{array}$ & $\begin{array}{l}\text { Potential } \\
\text { Increase due to } \\
\text { low calcium } \\
\text { intake }\end{array}$ & Potential Increase & Increase & $\begin{array}{l}\text { Potential increased risk due to } \\
\text { low calcium intake and resultant } \\
\text { high urinary Oxalate content. }\end{array}$ \\
\hline
\end{tabular}

This logically leads to the assumption that low carb diets would reduce the risk of hypercalciuria for new stone formation. This positive effect of low carb diets, however, is counterbalanced by the increase in protein intake, to compensate for the necessary caloric requirements. This increase in protein can be a factor for hypercalciuria as will be detailed in the next section dealing with protein rich diets. Nonetheless, even with this effect of hypercalciuria due to the increased protein intake, Friedman et al. demonstrated that no new kidney stone formation was associated with a low carb, protein rich diet [24].

\subsubsection{Oxalate}

Fructose (largely known as "fruit sugar") and xylitol (a sugar substitutive and added sweetener) are the two sugars demonstrated to influence oxalate synthesis via the glyoxylate pathway. Previous works, mainly by Nguyen et al. in the 1980s and 1990s, showed that dietary intake of carbs and substituents like xylitol resulted in hyperoxaluria [20,21]; however, a review by Holmes et al. suggested that the consumed amounts that increase oxalate synthesis are not likely to be found in a normal diet [25].

\subsubsection{Uric Acid}

One of the most important, yet largely overlooked, is the connection between carbohydrate intake in the diet and the rise of uric acid levels with the subsequent risk for uric acid 
stones. The connection lies with the fact that fructose metabolism significantly promotes ATP degradation to AMP, a precursor of uric acid production, and this can further promote purine synthesis and elevation of uric acid levels [26,27].

Indeed, one of the roots of the obesity epidemic is the introduction in 1967 of the high fructose corn syrup (HFCS), the use of which was popularized by an aggressive marketing campaign, in addition to certain "advantages" in comparison to the traditional cane sugar production, mainly in domains of transportation and manufacture. The use of HFCS in soda beverages was responsible for the even more dramatic increase in its consumption by all segments of the society, adults and minors alike, with a tremendous increase in the daily caloric intake of consumers [28,29].

Large epidemiological studies such as the NHANES III study and the HPFS study both showed that fructose ingestion is associated with increased serum uric acid levels [30,31].

In a study evaluating the effects of fructose ingestion on risk factors for KSD, Johnson et al. evaluated 33 healthy adults after ingestion of fructose daily for two weeks. The results showed an increase in blood uric acid, an increase in urine oxalate, and a decrease in urinary $\mathrm{pH}$ and magnesium [32]. The results also showed a trend for a higher level of urine uric acid and a lower level of urinary citrate.

All of the above drives one to the logical assumption that reduction of carbohydrate intake in the diet may avoid increases in urine calcium, oxalate and uric acid levels. However, a uniform conclusion for all low carb diets regarding the risk to develop KSD is not possible. This is mainly due to the variability among different low carb diets under the same umbrella, in a matter of carbohydrate percentage within the diet, in addition to the fact that any benefit of carbs reduction in the diet may be counterbalanced by an increase in protein consumption and the resultant hypercalciuria. The increase in fruits and vegetables' intake, in order to consume "good" carbs instead of "bad" carbs, probably plays a protective role against urinary stone formation by increasing urinary citrate and dietary fibers. One major issue of concerns, however, is the long-term safety of very low-carb "keto" diets. Sampath et al. suggested that "keto" diets, mainly used in the long term for therapeutic purposes in drug refractory epilepsy in children, can increase the risk of KSD due to hypercalciuria [33]. Maintaining sufficient fluid intake for adequate urine production, and urine alkalinization, in addition to periodic renal ultrasound to screen for stones, are all recommended measures [33,34].

\subsection{High Protein Diet}

Intake of animal protein in the diet has significantly increased in the last several decades with the adoption of a western industrial diet in growing parts of the world. The recommended daily intake of protein in the diet per day is $0.8-1 \mathrm{~g}$ protein $/ \mathrm{kg}$ body weight [35], corresponding to around $15-25 \%$ of daily caloric intake. The source of our dietary protein can be animal protein (meat, fish, poultry, eggs) or dairy proteins, in addition to proteins from vegetables. The most popular protein rich diet is the Dukan diet, a high protein, low carb and low fat diet [36]. In addition, many low carb diets include high protein intake, to compensate for the reduced caloric intake from carbohydrates [10]. As will be explored below, previous studies have suggested that a high protein intake increased the risk for urinary stone formation due to its effects on urine calcium, uric acid, oxalate and citrate $[22,37,38]$, while a low protein diet played a protective role [39].

\subsubsection{Calcium}

A high animal protein diet can significantly increase the acid load on the body [40]. In addition, protein rich diets induce an increase in urine calcium excretion, lower urine $\mathrm{pH}$ and lower urine citrate levels [41,42]. This has also raised concerns regarding increased bone reabsorption and possible resultant osteoporosis, even in younger adults. However, later studies suggest that, despite the resultant hypercalciuria, protein rich diets do not seem to influence body calcium balance and do not lead to calcium bone loss [43]. In fact, the hypercalciuria might be the result of increased intestinal absorption of calcium, and 
some authors suggest that long-term high-protein intake might even increase bone mineral density, through increased intestinal calcium absorption, reduced levels of parathyroid hormone, and higher circulating levels of IGF-1, an anabolic hormone that increases bone mass [44].

\subsubsection{Uric Acid}

Diets with high intake of purine rich sources (e.g., animal meats, fish, seafood) increase the levels of uric acid levels considerably, thereby elevating the risk for uric acid stone formation. In a small study of 10 male adults, intake of a vegetarian diet rather than a diet containing animal protein, reduced uric acid crystallization by $93 \%$ [45]. The source of dietary protein needs to be considered as well, as fish lead to a higher level of uric acid in the urine than animal meat protein, for example [46].

\subsubsection{Oxalate}

The relationship between protein rich diets and oxalate metabolism is not as extensively evaluated as that for calcium. Previous studies have suggested that, in normal subjects with a high intake of dietary proteins, the catabolism of amino acids did not increase endogenous oxalate synthesis [47]. Another study demonstrated that a protein rich diet increased urinary oxalate excretion in calcium oxalate stone formers but not in controls [48].

\subsubsection{Citrate}

Breslau et al. demonstrated that citrate excretion in the urine was reduced with increased animal protein intake, probably due to the associated acid load and an increase in renal tubular reabsorption [49].

In conclusion, a high protein intake in the diet increases net acid load, lowers urine $\mathrm{pH}$ and citrate excretion, in addition to an increase in uric acid levels. It is also associated with an increase in urine calcium excretion. However, if protein rich diets are associated with sufficient vegetables and fruits intake, the deleterious effect mentioned above can be counterbalanced and the risk for urinary stone formation can be reduced [50]. Moreover, the source of protein in the diet, whether animal/dairy or plant protein, needs to be taken into account. In a recent large study, for example, Shu et al. suggested that plant-based proteins did not increase the risk for stone formation in comparison with animal-based proteins [51].

In addition, another high protein diet worth mentioning, due to its recent popularity, is the Paleolithic or simply "Paleo" diet-. In this diet, aimed to mimic our hunter-gatherer ancestors in the pre-agricultural era, all processed food like cereals and dairy products are excluded, and instead, only unprocessed food like meat, eggs, oils, nuts, and fresh fruits and vegetables are included [52]. The concept behind this diet is that our genome is better adapted to the diet our ancestors adhered to for millions of years of development before the agricultural revolution in the last 10,000 years. This diet might indeed be advantageous in terms of weight loss and control of risk factors for the metabolic syndrome [53]. Regarding urinary stone risk factors, the intake of fresh fruits and vegetables is supposed to produce and net alkaline load to counterbalance the increased protein intake. However, it is the absence of sufficient calcium intake in the diet that is a source of concern [54], which might put the subject at increased risk of calcium oxalate stone formation due to the potential increased hyper-oxaluria [55].

\subsection{Vegetarian Diets}

Even if there are different typologies of vegetarianism [56], all vegetarian diets are oriented towards the intake of legumes, fresh and uncooked fruit, soy products (i.e., tofu), nuts, seeds, and whole grains, while abstaining from eating meat or poultry. However, sometimes their diets may include fish and dairy products [56,57]. 
The reason why most vegetarians take this path and avoid meat products are numerous - for instance, a deep concern about animal care and welfare, religious and cultural beliefs and personal health $[56,58,59]$. Many studies have demonstrated its relationship with weight loss [60-65] and a decrease in abdominal subcutaneous and visceral fat $[62,66]$. Moreover, vegetarian diets are of interest in the diabetic population due to the increased insulin sensitivity they offer, more than the one offered by the conventional diabetic diet (isocaloric) [66]; and in the metabolic syndrome population because of the reduction in total cholesterol [66] and low-density lipoprotein (LDL) $[62,64,66]$. In patients with hypertension, it has been demonstrated that this type of diet improves cardiovascular parameters $[67,68]$ and reverse coronary artery disease [67]. However, it is important to note that, despite having all those beneficial aspects mentioned before, these diets are also related with an increased urinary oxalate excretion, compared to a normal diet [69]. Oxalate-rich diets, such as vegetarian ones, increase the intestinal absorption of oxalate and can cause hyperoxaluria [70].

It is important to note that oxalate absorption is also influenced by other factors, mainly nutritional ones. For instance, both calcium and magnesium can bind to the oxalate to form an insoluble complex in the gut that is eliminated in the feces, limiting its absorption and urinary excretion [71,72]. Another one is the dietary phytic acid, which reduces the intestinal absorption of calcium by binding to it [73]. Thomas et al. observed that the mean intestinal oxalate absorption rate and the mean urinary excretion rate increased only in those who had a low-oxalate vegetarian diet (70 mg oxalate) by $72 \%$ and $30 \%$, respectively, compared to those who followed a standard mixed diet (60 mg oxalate) [74]. However, the high-oxalate vegetarian (300 mg oxalate) diet had a similar mean urinary oxalate excretion to the mixed diet [74]. The reason for this can be explained by the role other nutritional components play, creating a balance.

All these factors should be taken into count and controlled by individuals going on a vegetarian path. Especially in calcium oxalate stone patients, this diet can only be recommended if it contains the suggested dietary amounts of calcium and magnesium, given at the time of oxalate ingestion, and if it excludes food components that chelates dietary calcium, as the phytic acid [74]. Adequate calcium intake per day needs to be maintained because a reduction from the standard $1200 \mathrm{mg} /$ day can increase the oxalate dietary absorption by fivefold [72].

Additionally, a balanced vegetarian diet with an adequate fluid intake and a high alkali-load with fruits and vegetables make it possible to have an alkali urinary $\mathrm{pH}$, helping to reduce the risk of uric acid crystallization compared to the regular meat-based diets and therefore decrease the risk of urid acid stones [45].

In summary, a balanced vegetarian diet, which concerns a high intake of fruits and vegetables and low intake in animal proteins, low-fat dairy products, and salt, may help to reduce the risk of stone kidney disease $[75,76]$.

\subsection{Vegan Diets}

In contrast to vegetarian diets, vegan diets exclude animal ingredients in general, animal products (i.e., eggs, dairy, honey), garlic, onion, spring onion, scallions and leeks, and some sugars that used bine char in their manufacturing (i.e., cane sugar) [57]. This type of diet is rich in oxalate, coming from the vegetables and grains, and poor in calcium, due to its exclusion of dairy products [75]. These two features may relate vegan diet with calcium oxalate stone formation.

Furthermore, dairy products have been demonstrated to have lower circulating concentrations of urate after its consumption and also to increase uric acid excretion [77,78]. Therefore, in vegan diets, the lack of dairy products is associated with higher serum uric acid, hyperuricosuria, and uric acid stones [79]. Uric acid levels are higher than the one found in meat eaters, fish eaters, and vegetarians [80].

The real effect that this diet has in urinary stones formation is still under investigation and needs further study. However, because of the potential risks that it poses for increasing 
urinary risk factors, to date, we cannot recommend it as a safe diet for kidney stone prevention.

\subsection{The DASH Diet}

The Dietary Approaches to Stop Hypertension (DASH diet) is a diet for which the connection with KSD was evaluated more thoroughly. This diet, rich in fruits and vegetables, with low-moderate intake of fat and proteins, respectively, had a reduced acid load compared to control ( $31 \mathrm{vs.} 78 \mathrm{mEq} / \mathrm{d}$ of endogenous acid production), and it had a lower risk for stone formation [75,81]. Additionally, consuming a high number of fruits and vegetables and low-fat dairy products increased the urinary volume and urinary citrate, leading to a reduced risk of stone events by up to $45 \%[75,82,83]$. This potentially protective effect was also echoed in the next diet, the Mediterranean diet, which differs from the DASH diet mainly by recommending a moderate intake of fat, instead of low or no-fat-only dairy products, as recommended by the DASH diet, while sharing a similar set of dietary recommendations regarding the high intake of fruit and vegetables.

\subsection{The Mediterrenean Diet}

The Mediterranean diet might play an important protective role against urinary stone formation. This was thoroughly demonstrated in a detailed study by Prieto et al., in which the calcium and uric acid urinary crystallization risks were calculated [84]. The authors found that a high consumption of vegetables was the strongest dietary factor for decreased calcium crystallization risk. However, for uric acid crystallization risk, it was a combination of low animal protein intake and healthy fatty acids intake, such as unsaturated fat from olive oil, for example. It should be noted, however, that the study population was composed of an elderly, mainly overweight population with metabolic syndrome. Nonetheless, given the close relationship between the metabolic syndrome and nephrolithiasis, the results are encouraging and might hint at a larger benefit for the wider population. However, this needs to be demonstrated in large heterogenic-cohort studies.

In conclusion, it seems that both the DASH and the Mediterranean diets exert a protective role mainly attributed to the lower intake of animal protein and high intake of fruits and vegetables.

\subsection{Other Diet Types}

Diets that are not modifications of the above-mentioned categories are usually diets comprising intermittent fasting periods. One example is the moon diet (also named the werewolf or lunar diet), which consists of short-term fasting periods of $24 \mathrm{~h}$, on a monthly basis, during the full moon or new moon period [85]. In this diet, water intake is continued, and due to its short period, there is probably no change in urinary risk factors for KSD.

Detox diets are usually comprised of a short period of fasting, followed by a diet based on fruits and vegetables and fresh juices. These diets probably do not increase the risk for urinary stone formation, as long as water intake is continued, and calcium intake is maintained within the normal limits of 1-1.2 g per day.

\section{Conclusions}

Given the close relationship between KSD and obesity, it is surprising to find how limited the literature is when searching for the effects of diets to treat obesity, on the risk for KSD, as highlighted in the PRISMA flow chart. The drawing of clear conclusions for every diet is practically impossible, due to the variability of diet types, the presence of modifications of each diet that appear every few years, and the absence of long-term follow up studies. For this reason, this review studied the effects of each diet type on individual urinary risk factors for KSD. Nonetheless, the reduction of carbohydrate in the diet, while counterbalancing protein rich diets with sufficient intake of fruits and vegetables, seems to play a protective role against KSD formation. These conclusions need to be supported 
by additional research evaluating the direct relationship between KSD and each diet type, maintained for a sufficient time-period, to truly represent the change in urinary risk factors.

Author Contributions: Y.B., Project development, Data Collection, Manuscript writing. M.C., Data collection and analysis, Manuscript writing. B.S., Project development, Manuscript editing. All authors have read and agreed to the published version of the manuscript.

Funding: The authors did not receive support from any organization for the submitted work. This research is a review paper and does not involve research in humans or animals.

Conflicts of Interest: The authors have no conflict of interest to declare that are relevant to the content of this article.

\section{References}

1. Romero, V.; Akpinar, H.; Assimos, D.G. Kidney Stones: A Global Picture of Prevalence, Incidence, and Associated Risk Factors. Rev. Urol. 2010, 12, 86-96.

2. Sorokin, I.; Mamoulakis, C.; Miyazawa, K.; Rodgers, A.; Talati, J.; Lotan, Y. Epidemiology of stone disease across the world. World J. Urol. 2017, 35, 1301-1320. [CrossRef] [PubMed]

3. Taylor, E.N.; Stampfer, M.J.; Curhan, G.C. Obesity, Weight Gain, and the Risk of Kidney Stones. JAMA 2005, 293, 455-462. [CrossRef] [PubMed]

4. Heilberg, I.P.; Goldfarb, D. Optimum Nutrition for Kidney Stone Disease. Adv. Chronic Kidney Dis. 2013, 20, 165-174. [CrossRef]

5. Ziemba, J.B.; Matlaga, B.R. Epidemiology and economics of nephrolithiasis. Investig. Clin. Urol. 2017, 58, 299-306. [CrossRef] [PubMed]

6. Oh, R.; Gilani, B.; Uppaluri, K.R. Low Carbohydrate Diet. In StatPearls; StatPearls Publishing: Treasure Island, FL, USA, 2021.

7. Khan, S.R.; Pearle, M.S.; Robertson, W.G.; Gambaro, G.; Canales, B.K.; Doizi, S.; Traxer, O.; Tiselius, H.-G. Kidney stones. Nat. Rev. Dis. Prim. 2016, 2, 16008. [CrossRef]

8. Gul, Z.; Monga, M. Medical and Dietary Therapy for Kidney Stone Prevention. Korean J. Urol. 2014, 55, 775-779. [CrossRef]

9. Institute of Medicine. Dietary Reference Intakes for Energy, Carbohydrate, Fiber, Fat, Fatty Acids, Cholesterol, Protein, and Amino Acids; National Academies Press: Washington, DC, USA, 2005. [CrossRef]

10. Freire, R. Scientific evidence of diets for weight loss: Different macronutrient composition, intermittent fasting, and popular diets. Nutrition 2019, 69, 110549. [CrossRef]

11. Passos, J.A.; Vasconcellos-Silva, P.R.; Santos, L.A.D.S. Ciclos de atenção a dietas da moda e tendências de busca na internet pelo Google trends. Ciência Saúde Coletiva 2020, 25, 2615-2631. [CrossRef]

12. Hite, A.H.; Berkowitz, V.G.; Berkowitz, K. Low-Carbohydrate Diet Review. Nutr. Clin. Pract. 2011, 26, 300-308. [CrossRef]

13. Ludwig, D.S.; Ebbeling, C.B. The Carbohydrate-Insulin Model of Obesity. JAMA Intern. Med. 2018, 178, 1098-1103. [CrossRef]

14. Johnston, B.C.; Kanters, S.; Bandayrel, K.; Wu, P.; Naji, F.; Siemieniuk, R.A.; Ball, G.D.C.; Busse, J.; Thorlund, K.; Guyatt, G.; et al. Comparison of Weight Loss among Named Diet Programs in Overweight and Obese Adults. JAMA 2014, 312, 923-933. [CrossRef]

15. Ge, L.; Sadeghirad, B.; Ball, G.D.C.; Da Costa, B.R.; Hitchcock, C.L.; Svendrovski, A.; Kiflen, R.; Quadri, K.; Kwon, H.Y.; Karamouzian, M.; et al. Comparison of dietary macronutrient patterns of 14 popular named dietary programmes for weight and cardiovascular risk factor reduction in adults: Systematic review and network meta-analysis of randomised trials. BMJ 2020, 369, m696. [CrossRef] [PubMed]

16. Gardner, C.D.; Kiazand, A.; Alhassan, S.; Kim, S.; Stafford, R.S.; Balise, R.R.; Kraemer, H.C.; King, A.C. Comparison of the Atkins, Zone, Ornish, and LEARN diets for change in weight and related risk factors among overweight premenopausal women: The A TO Z Weight Loss Study: A randomized trial. JAMA 2007, 297, 969-977. [CrossRef] [PubMed]

17. Goff, S.L.; Foody, J.M.; Inzucchi, S.; Katz, D.L.; Mayne, S.T.; Krumholz, H.M. Brief report: Nutrition and weight loss information in a popular diet book: Is it fact, fiction, or something in between? J. Gen. Intern. Med. 2006, 21, 769-774. [CrossRef] [PubMed]

18. Southbeach Diet-The Handbook. Available online: https://www.southbeachdiet.com/pdf/sbd/SB-HANDBOOK.pdf (accessed on 20 September 2021).

19. Kossoff, E.; Wang, H.-S.; Eh, K.; Hs, W. Dietary Therapies for Epilepsy. Biomed. J. 2013, 36, 2. [CrossRef]

20. Nguyen, N.; Dumoulin, G.; Wolf, J.; Bourderont, D.; Berthelay, S. Urinary Oxalate and Calcium Excretion in Response to Oral Glucose Load in Man. Horm. Metab. Res. 1986, 18, 869-870. [CrossRef] [PubMed]

21. Nguyen, N.U.; Dumoulin, G.; Henriet, M.T.; Berthelay, S.; Regnard, J. Carbohydrate metabolism and urinary excretion of calcium and oxalate after ingestion of polyol sweeteners. J. Clin. Endocrinol. Metab. 1993, 77, 388-392. [CrossRef]

22. Curhan, G.C.; Willett, W.C.; Speizer, F.E.; Spiegelman, D.; Stampfer, M.J. Comparison of Dietary Calcium with Supplemental Calcium and Other Nutrients as Factors Affecting the Risk for Kidney Stones in Women. Ann. Intern. Med. 1997, 126, 497-504. [CrossRef]

23. Yoon, V.; Adams-Huet, B.; Sakhaee, K.; Maalouf, N.M. Hyperinsulinemia and Urinary Calcium Excretion in Calcium Stone Formers with Idiopathic Hypercalciuria. J. Clin. Endocrinol. Metab. 2013, 98, 2589-2594. [CrossRef] 
24. Friedman, A.N.; Ogden, L.G.; Foster, G.D.; Klein, S.; Stein, R.; Miller, B.; Hill, J.O.; Brill, C.; Bailer, B.; Rosenbaum, D.R.; et al. Comparative Effects of Low-Carbohydrate High-Protein versus Low-Fat Diets on the Kidney. Clin. J. Am. Soc. Nephrol. 2012, 7, 1103-1111. [CrossRef] [PubMed]

25. Holmes, R.; Assimos, D.G. Glyoxylate synthesis, and its modulation and influence on oxalate synthesis. J. Urol. 1998, 160, 1617-1624. [CrossRef]

26. Johnson, R.; Segal, M.S.; Sautin, Y.; Nakagawa, T.; Feig, D.I.; Kang, D.-H.; Gersch, M.S.; Benner, S.; Sánchez-Lozada, L.G. Potential role of sugar (fructose) in the epidemic of hypertension, obesity and the metabolic syndrome, diabetes, kidney disease, and cardiovascular disease. Am. J. Clin. Nutr. 2007, 86, 899-906. [PubMed]

27. Rho, Y.H.; Zhu, Y.; Choi, H.K. The Epidemiology of Uric Acid and Fructose. Semin. Nephrol. 2011, 31, 410-419. [CrossRef]

28. Hallfrisch, J. Metabolic effects of dietary fructose. FASEB J. 1990, 4, 2652-2660. [CrossRef]

29. Choi, H.K.; Mount, D.B.; Reginato, A.M. Pathogenesis of Gout. Ann. Intern. Med. 2005, 143, 499-516. [CrossRef]

30. Choi, H.K.; Curhan, G. Soft drinks, fructose consumption, and the risk of gout in men: Prospective cohort study. BMJ 2008, 336, 309-312. [CrossRef]

31. Choi, J.W.J.; Ford, E.S.; Gao, X.; Choi, H.K. Sugar-sweetened soft drinks, diet soft drinks, and serum uric acid level: The third national health and nutrition examination survey. Arthritis Rheum. 2007, 59, 109-116. [CrossRef]

32. Johnson, R.J.; Perez-Pozo, S.E.; Lillo, J.L.; Grases, F.; Schold, J.D.; Kuwabara, M.; Sato, Y.; Hernando, A.A.; Garcia, G.; Jensen, T.; et al. Fructose increases risk for kidney stones: Potential role in metabolic syndrome and heat stress. BMC Nephrol. 2018, 19, 315. [CrossRef]

33. Sampath, A.; Kossoff, E.H.; Furth, S.L.; Pyzik, P.L.; Vining, E.P.G. Kidney Stones and the Ketogenic Diet: Risk Factors and Prevention. J. Child. Neurol. 2007, 22, 375-378. [CrossRef]

34. Nassar, M.F.; El-Rashidy, O.F.; Abdelhamed, M.H.; Shata, M.O. Modified Atkins diet for drug-resistant epilepsy and the risk of urolithiasis. Pediatr. Res. 2021, 1-5. [CrossRef]

35. Richter, M.; Baerlocher, K.; Bauer, J.M.; Elmadfa, I.; Heseker, H.; Leschik-Bonnet, E.; Stangl, G.; Volkert, D.; Stehle, P.; on behalf of the German Nutrition Society (DGE). Revised Reference Values for the Intake of Protein. Ann. Nutr. Metab. 2019, 74, $242-250$. [CrossRef] [PubMed]

36. Available online: https://www.dukandiet.com/ (accessed on 15 September 2021).

37. Curhan, G.C.; Willett, W.C.; Rimm, E.B.; Stampfer, M.J. A Prospective Study of Dietary Calcium and Other Nutrients and the Risk of Symptomatic Kidney Stones. N. Engl. J. Med. 1993, 328, 833-838. [CrossRef] [PubMed]

38. Reddy, S.T.; Wang, C.-Y.; Sakhaee, K.; Brinkley, L.; Pak, C.Y. Effect of low-carbohydrate high-protein diets on acid-base balance, stone-forming propensity, and calcium metabolism. Am. J. Kidney Dis. 2002, 40, 265-274. [CrossRef]

39. Borghi, L.; Schianchi, T.; Meschi, T.; Guerra, A.; Allegri, F.; Maggiore, U.; Novarini, A. Comparison of two diets for the prevention of recurrent stones in idiopathic hypercal-ciuria. N. Engl. J. Med. 2002, 346, 77-84. [CrossRef]

40. Lemann, J.; Gray, R.W.; Maierhofer, W.J.; Cheung, H.S. The importance of renal net acid excretion as a determinant of fasting urinary calcium excretion. Kidney Int. 1986, 29, 743-746. [CrossRef]

41. Schuette, S.A.; Zemel, M.; Linkswiler, H.M. Studies on the Mechanism of Protein-Induced Hypercalciuria in Older Men and Women. J. Nutr. 1980, 110, 305-315. [CrossRef]

42. Robertson, W.G.; Heyburn, P.J.; Peacock, M.; Hanes, F.A.; Swaminathan, R. The Effect of High Animal Protein Intake on the Risk of Calcium Stone-Formation in the Urinary Tract. Clin. Sci. 1979, 57, 285-288. [CrossRef]

43. Calvez, J.; Poupin, N.; Chesneau, C.; Lassale, C.; Tome, D. Protein intake, calcium balance and health consequences. Eur. J. Clin. Nutr. 2011, 66, 281-295. [CrossRef] [PubMed]

44. Cao, J.J.; Nielsen, F.H. Acid diet (high-meat protein) effects on calcium metabolism and bone health. Curr. Opin. Clin. Nutr. Metab. Care 2010, 13, 698-702. [CrossRef]

45. Siener, R.; Hesse, A. The effect of a vegetarian and different omnivorous diets on urinary risk factors for uric acid stone formation. Eur. J. Nutr. 2003, 42, 332-337. [CrossRef] [PubMed]

46. Tracy, C.; Best, S.; Bagrodia, A.; Poindexter, J.R.; Adams-Huet, B.; Sakhaee, K.; Maalouf, N.; Pak, C.Y.; Pearle, M.S. Animal Protein and the Risk of Kidney Stones: A Comparative Metabolic Study of Animal Protein Sources. J. Urol. 2014, 192, 137-141. [CrossRef] [PubMed]

47. Knight, J.; Easter, L.H.; Neiberg, R.; Assimos, D.G.; Holmes, R.P. Increased protein intake on controlled oxalate diets does not increase urinary oxalate excretion. Urol. Res. 2009, 37, 63-68. [CrossRef]

48. Nguyen, Q.-V.; Kälin, A.; Drouve, U.; Casez, J.-P.; Jaeger, P. Sensitivity to meat protein intake and hyperoxaluria in idiopathic calcium stone formers. Kidney Int. 2001, 59, 2273-2281. [CrossRef] [PubMed]

49. Breslau, N.A.; Brinkley, L.; Hill, K.D.; Pak, C.Y.C. Relationship of Animal Protein-Rich Diet to Kidney Stone Formation and Calcium Metabolism. J. Clin. Endocrinol. Metab. 1988, 66, 140-146. [CrossRef]

50. Heaney, R.P.; Layman, D.K. Amount and type of protein influences bone health. Am. J. Clin. Nutr. 2008, 87, 1567S-1570S. [CrossRef]

51. Shu, X.; Calvert, J.K.; Cai, H.; Xiang, Y.-B.; Li, H.; Zheng, W.; Shu, X.-O.; Hsi, R.S. Plant and Animal Protein Intake and Risk of Incident Kidney Stones: Results from the Shanghai Men's and Women's Health Studies. J. Urol. 2019, 202, 1217-1223. [CrossRef] [PubMed]

52. Eaton, S.B.; Konner, M. Paleolithic Nutrition. N. Engl. J. Med. 1985, 312, 283-289. [CrossRef] 
53. Cordain, L.; Eaton, S.B.; Brand-Miller, J.; Mann, N.; Hill, K. The paradoxical nature of hunter-gatherer diets: Meat-based, yet non-atherogenic. Eur. J. Clin. Nutr. 2002, 56, S42-S52. [CrossRef]

54. Österdahl, M.; Kocturk, T.; Koochek, A.; Wändell, P.E. Effects of a short-term intervention with a paleolithic diet in healthy volunteers. Eur. J. Clin. Nutr. 2008, 62, 682-685. [CrossRef]

55. Trinchieri, A. Diet and renal stone formation. Minerva Med. 2013, 104, 41-54. [CrossRef] [PubMed]

56. Petti, A.; Palmieri, B.; Vadalà, M.; Laurino, C. Vegetarianism and veganism: Not only benefits but also gaps. A Review. Prog. Nutr. 2017, 19, 229-242. [CrossRef]

57. Brytek-Matera, A. Restrained Eating and Vegan, Vegetarian and Omnivore Dietary Intakes. Nutrients 2020, 12, 2133. Available online: https:/ / pubmed.ncbi.nlm.nih.gov/32709060/ (accessed on 15 September 2021). [CrossRef] [PubMed]

58. Beardsworth, A.; Keil, T. Health-related beliefs and dietary practices among vegetarians and vegans: A qualitative study. Health Educ. J. 1991, 50, 38-42. [CrossRef]

59. Fox, N.; Ward, K. Health, ethics and environment: A qualitative study of vegetarian motivations. Appetite 2008, 50, 422-429. [CrossRef] [PubMed]

60. Burke, L.E.; Warziski, M.; Styn, M.A.; Music, E.; Hudson, A.G.; Sereika, S.M. A randomized clinical trial of a standard versus vegetarian diet for weight loss: The impact of treatment preference. Int. J. Obes. 2008, 32, 166-176. Available online: https: / / pubmed.ncbi.nlm.nih.gov/17700579/ (accessed on 15 September 2021). [CrossRef]

61. Hakala, P.; Karvetti, R.L. Weight Reduction on Lactovegetarian and Mixed Diets. Changes in Weight, Nutrient Intake, Skinfold Thicknesses and Blood Pressure. Eur. J. Clin. Nutr. 1989, 43, 421-430. Available online: https://pubmed.ncbi.nlm.nih.gov/274396 $5 /$ (accessed on 15 September 2021).

62. Sofi, F.; Dinu, M.; Pagliai, G.; Cesari, F.; Gori, A.M.; Sereni, A.; Becatti, M.; Fiorillo, C.; Marcucci, R.; Casini, A. Low-Calorie Vegetarian versus Mediterranean Diets for Reducing Body Weight and Improving Cardiovascular Risk Profile. Circulation 2018, 137, 1103-1113. [CrossRef]

63. Arntzenius, A.C. Diet, Lipoproteins and the Progression of Coronary Atherosclerosis: The Leiden Intervention Trial. Drugs 1986, 31, 61-65. [CrossRef]

64. Marshall, D.A.; Walizer, E.M.; Vernalis, M.N. Achievement of Heart Health Characteristics through Participation in an Intensive Lifestyle Change Program (Coronary Artery Disease Reversal Study). J. Cardiopulm. Rehabil. Prev. 2009, 29, 84-94. [CrossRef]

65. Slavícek, J.; Kittnar, O.; Fraser, G.E.; Medová, E.; Konecná, J.; Zizka, R.; Dohnalová, A.; Novák, V. Lifestyle Decreases Risk Factors for Cardiovascular Diseases. Cent. Eur. J. Public Health 2008, 16, 161-164. Available online: https:/ / pubmed.ncbi.nlm.nih.gov/19 256282/ (accessed on 15 September 2021). [CrossRef] [PubMed]

66. Kahleova, H.; Matoulek, M.; Malinska, H.; Oliyarnik, O.; Kazdova, L.; Neskudla, T.; Skoch, A.; Hajek, M.; Hill, M.; Kahle, M.; et al. Vegetarian Diet Improves Insulin Resistance and Oxidative Stress Markers More Than Conventional Diet in Subjects with Type2 Diabetes. Diabet. Med. 2011, 28, 549-559. Available online: https://pubmed.ncbi.nlm.nih.gov/21480966/ (accessed on 15 September 2021). [CrossRef] [PubMed]

67. Ornish, D.; Scherwitz, L.W.; Billings, J.H.; Gould, K.L.; Merritt, T.A.; Sparler, S.; Armstrong, W.T.; Ports, T.A.; Kirkeeide, R.L.; Hogeboom, C.; et al. Intensive Lifestyle Changes for Reversal of Coronary Heart Disease. JAMA 1998, 280, 2001-2007. [CrossRef] [PubMed]

68. Dod, H.S.; Bhardwaj, R.; Sajja, V.; Weidner, G.; Hobbs, G.R.; Konat, G.W.; Manivannan, S.; Gharib, W.; Warden, B.E.; Nanda, N.C.; et al. Effect of Intensive Lifestyle Changes on Endothelial Function and on Inflammatory Markers of Atherosclerosis. Am. J. Cardiol. 2010, 105, 362-367. [CrossRef] [PubMed]

69. Siener, R.; Hesse, A. The Effect of Different Diets on Urine Composition and the Risk of Calcium Oxalate Crystallisation in Healthy Subjects. Eur. Urol. 2002, 42, 289-296. Available online: https:/ / pubmed.ncbi.nlm.nih.gov/12234515/ (accessed on 15 September 2021). [CrossRef]

70. Zimmermann, D.J.; Hesse, A.; von Unruh, G.E. Influence of a high-oxalate diet on intestinal oxalate absorption. World J. Urol. 2005, 23, 324-329. [CrossRef]

71. Liebman, M.; Costa, G. Effects of Calcium and Magnesium on Urinary Oxalate Excretion after Oxalate Loads. J. Urol. 2000, 163, 1565-1569. Available online: http:/ / www.jurology.com/doi/10.1016/S0022-5347\%2805\%2967680-X (accessed on 15 September 2021). [CrossRef]

72. Von Unruh, G.E.; Voss, S.; Sauerbruch, T.; Hesse, A. Dependence of Oxalate Absorption on the Daily Calcium Intake. J. Am. Soc. Nephrol. 2004, 15, 1567-1573. Available online: https:// pubmed.ncbi.nlm.nih.gov/15153567/ (accessed on 15 September 2021). [CrossRef]

73. Ebisuno, S.; Morimoto, S.; Yasukawa, S.; Ohkawa, T. Results of Long-term Rice Bran Treatment on Stone Recurrence in Hypercalciuric Patients. BJU Int. 1991, 67, 237-240. [CrossRef]

74. Thomas, E.; von Unruh, G.E.; Hesse, A. Influence of a low- and a high-oxalate vegetarian diet on intestinal oxalate absorption and urinary excretion. Eur. J. Clin. Nutr. 2007, 62, 1090-1097. [CrossRef]

75. Ferraro, P.M.; Bargagli, M.; Trinchieri, A.; Gambaro, G. Risk of Kidney Stones: Influence of Dietary Factors, Dietary Patterns, and Vegetarian-Vegan Diets. Nutrients 2020, 12, 779. [CrossRef] [PubMed]

76. Turney, B.W.; Appleby, P.N.; Reynard, J.M.; Noble, J.G.; Key, T.J.; Allen, N.E. Diet and risk of kidney stones in the Oxford cohort of the European Prospective Investigation into Cancer and Nutrition (EPIC). Eur. J. Epidemiol. 2014, 29, 363-369. [CrossRef] [PubMed] 
77. Dalbeth, N.; Wong, S.; Gamble, G.; Horne, A.; Mason, B.; Pool, B.; Fairbanks, L.; McQueen, F.M.; Cornish, J.; Reid, I.; et al. Acute effect of milk on serum urate concentrations: A randomised controlled crossover trial. Ann. Rheum. Dis. 2010, 69, 1677-1682. [CrossRef] [PubMed]

78. Dalbeth, N.; Palmano, K. Effects of Dairy Intake on Hyperuricemia and Gout. Curr. Rheumatol. Rep. 2010, 13, 132-137. [CrossRef]

79. Nouvenne, A.; Ticinesi, A.; Morelli, I.; Guida, L.; Borghi, L.; Meschi, T. Fad Diets and Their Effect on Urinary Stone Formation. In Translational Andrology and Urology; AME Publishing Company: Hong Kong, China, 2014; Volume 3, pp. 303-312. Available online: https: / / pubmed.ncbi.nlm.nih.gov/26816783/ (accessed on 15 September 2021).

80. Schmidt, J.A.; Crowe, F.L.; Appleby, P.N.; Key, T.J.; Travis, R.C. Serum Uric Acid Concentrations in Meat Eaters, Fish Eaters, Vege-tarians and Vegans: A Cross-Sectional Analysis in the EPIC-Oxford Cohort. PLoS ONE 2013, 8, e56339. Available online: https:/ / pubmed.ncbi.nlm.nih.gov/23418557/ (accessed on 15 September 2021).

81. Scialla, J.J.; Anderson, C.A.M. Dietary Acid Load: A Novel Nutritional Target in Chronic Kidney Disease? Adv. Chronic Kidney Dis. 2013, 20, 141-149. Available online: https:/ / pubmed.ncbi.nlm.nih.gov/23439373/ (accessed on 23 September 2021). [CrossRef]

82. Taylor, E.N.; Fung, T.T.; Curhan, G.C. DASH-Style Diet Associates with Reduced Risk for Kidney Stones. J. Am. Soc. Nephrol. 2009, 20, 2253-2259. [CrossRef]

83. Taylor, E.N.; Stampfer, M.J.; Mount, D.B.; Curhan, G.C. DASH-Style Diet and 24-Hour Urine Composition. Clin. J. Am. Soc. Nephrol. 2010, 5, 2315-2322. [CrossRef]

84. Prieto, R.M.; Rodriguez, A.; Sanchis, P.; Morey, M.; Fiol, M.; Grases, F.; Castañer, O.; Martínez-González, M.A.; Salas-Salvadó, J.; Romaguera, D.; et al. Association of Adherence to The Mediterranean Diet with Urinary Factors Favoring Renal Lithiasis: Cross-Sectional Study of Overweight Individuals with Metabolic Syndrome. Nutrients 2019, 11, 1708. [CrossRef]

85. Available online: https:/ / www.moonconnection.com/moon-diet.phtml (accessed on 20 September 2021). 